\title{
Teaching - Learning of Business Sustainable Development: Business Stability as the Function of the Effective Business Process Indicators
}

\author{
Ruizan Mekvabidze \\ Gori State Teaching University, 53 Ilia Chavchavadze Ave, Gori, Georgia \\ gsu@grt.ge
}

\begin{abstract}
Higher education of the business process optimization in the frame of the globalization process with the fast IT development must be considered as business management Performance of a competitive enterprise. At the same time, modeling and management processes and methods and effective model design should be able to solve the real problems and apply current knowledge and professional practice of optimal decision making for business strategy management and sustainable development. The presented research paper analyzes modeling business sustainable development by finding the items connected and supported by the optimization approaches that factor which is responsible for business development evaluation. Based on the analysis, business sustainability (BS) has combined the three main factors of business sustainable development evaluation model-building, optimal decision-making, and strategy management as a tool for the business process design according to the transformation of business education for the understanding approaches of business sustainability. The scientific work focuses on a view of the functional relationship of business sustainable development and influence of the educational indicators of model building, decision making, knowledge management for the developing study module for Master of Business Administration \&Management (MAB\&M) and creating the framework of the functional relationship between them. Besides, there is considering the current teaching-learning problems discussion according to the Business sustainable development evaluation through the follows as are: (1) Business sustainability as a function of model-building, optimal decision-making, and strategy management; (2) Understanding of the modeling process in the frame of research and analyzing complex issues and problems in business; (3) Making the decision in the context of the possibility of approaches for transformation teaching-learning process by introducing research component with practice; (4) Applying best-practice model design to real business problems, discussing the problems, and analyzing them; (5) Optimal decision-making as a result of model-building and the strategy management; (6) Business Education Performance as a way to the sustainability business process.
\end{abstract}


Keywords: Real problems of business sustainability, business education indicators, the teaching-learning approaches to business stability.

\section{Introduction}

Globalization, the fast development of IT, the current pandemic situation are becoming a great challenge in higher education for the need for curricula change. A curriculum approach provides a framework within which practice would be able to critically reflect on what is meant by internationalized teaching and learning. At the same time, we have to answer the questions (Kerlinger 1986: 279) as these answers are responsible for the results of preparing the new generation for a competitive job market and creating a sustainable development environment. "We stand on the brink of a technological revolution that will fundamentally alter the way we live, work..." (Klaus Schwab, 2019). But we are facing an education crisis and challenges in many fields, not less than economics or business. An ongoing global recession caused by the COVID-19 has brought not only an economic crisis but also the education crisis, new requirements for educational institutions, and dictates to investigate the approaches of integration of T-L-R-P (Teaching-LearningResearch-Practice (R. Mekvabidze, 2015) that is the baseline and the necessity of intellectual and creative thinking for the formation of the world new thinkers. We need to know: what and how students learn, and why the knowledge achieved is of importance would then become open to reflect on, and in turn, open up for the possibility to critically examine which features need to be changed, or supported and promoted in practice and we need to provide the eligible research as research offers an opportunity to contribute to a body of knowledge and influence change. Research is a key tool in informed decision-making. It can be central to determining (Mekvabidze R., 2021): what and how we should do, what and how we can do, how we will do it, and why the knowledge performance is important, how well we have done it, critically examining which features need to be changed, supported, and promoted in practice, how to develop Critical Thinking and Skills for the transformation of the education process for the new thinkers as it includes the relationship between critical thinking, student's motivation, student's engagement in the study process, student achievement. In the realization of the T-L- R-P process and the main trends can be formulated as are: critical thinking, new approaches to student and teacher relationships, stimulating reflection about the future of education, determining robust data on trends, strategic thinking.

On the one hand, increasing critical thinking is related to considering research elements more intensively in the study process and, on the other hand, developing the applied skills directed to effective problem-solving and optimal decision-making. We have to consider these two versions for their integration and implement them in Higher education curricula as Higher Education should reinforce innovation of integrating T-L-R-P for sustainable development of business and economics with a 
sustainable learning environment and formation of the global citizen.

What problem lies at the bottom of it? In HE, this responsibility for the world takes the form of modern education (Ruizan Mekvabidze, 2015) to build and reform strategies to evaluate risks and deal with uncertainties of the modern approaches to educating young business providers who would create new inventions and strategies in the diverse business field for business sustainability development. But, as knowledge is developing under research and practice, Higher Educational Institutions must promote research and research design. Bur research requires conceptual understanding, and it must be directed to discover the theory from data and data processing and obtain the results for innovation used for future performance.

\section{Business stability and its development}

Under the influence of the fast development of IT, the world changes faster. It needs more creative individuals who can think practically and provide an optimal business process focused on stability. The Business Stability (BS) needs research with the required design with answers to the problems and the questions for understanding its practical potential: What is the better way of Business Sustainability teaching? How do we work out the study module Business Sustainability development for teaching?

At the same time, education lags from IT development, which creates a problem in teaching those disciplines whose development depends on IT, and between them are optimal decision making, business modeling, strategic management, and research projects especially for the master of business administration and management (MBA\&M). This is one of the main problems for graduates to reach the specific academic and professional level to competitive job markets (Sherry E. Sullivan, Yehuda Baruch, 2009). In this situation, it is important to focus on education to move forward and offer useful opportunities to MBA\&M students and direct them to Learning, Research, Practice, and Experience that provide the needed skills for business stability based on the market requirements (Mekvabidze R., 2015).

The master of business administration and management (MBA\&M) is one of the most popular academic qualifications, designed to develop skills within business and management with the management profession. The main objective of management education is to prepare graduates to be outstanding managers, leaders, and professionals as MBA\&M students have to learn and develop theoretical models, research methodologies, and research skills and the research thesis or business project independently that allows students to gain the research skills that will serve them well in their future careers (Sherry e. Sullivan, Yehuda Baruch, 2009). The models of research and knowledge creation should be given greater prominence (Bakradze L. 2013). A study of Master of Business Administration 
programs must be focused on developing strategic management skills, mainly and giving the perception of a professional manager (Fred R. David, 2016).

An ongoing education challenge for business sustainability suggests that MBA\&M students are exposed to complex decision problems, and the students have to increase their managerial judgment and their professionalism (Mekvabidze R. 2016). In the USA, most of the graduates have work experience when they start the program, and this program is an additional education based on prior knowledge from work. Outside the USA, MBA\&M programs are as education after their bachelor's degree and are more academically presented. But, as a result, the theoretical and practical understanding of a subject by a person is provided by research that units all skills for specialist's formation (Mekvabidze R., 2018).

In this case, In the teaching process, data analytics, knowledge management, optimal Decision-making, and research practice tracks are very important to improve students' knowledge for better strategic decision-making. Therefore, the organized teaching of the research methods with utilizing the above subjects tracks is an emerging for graduates to become more analytical, more thinking individuals that are the main aspects of the new generation of the 21st century (Mekvabidze, 2020). It is clear that information systems support the subjects above. Still, education lags from ICT development, which creates a problem in teaching these disciplines for the students of MBA\&M. This is one of the main problems for graduates to reach the specific academic and professional level.

At the same time, higher education institutions have to be more responsible for answering the demands of the new era and activating the changes according to the fast-developing tools of IT. In this case, This moment is addressed to enrich the educational triangle teaching-learning - research - practice with experience and practice. As MBA\&M students' practical skills develop under the research process, Higher Educational Institutions (HEI) have to promote research and research design with a conceptual understanding of innovation and synthesis of knowledge management and optimal decision-making strategies that are crucial factors for the formation of the specialist with high qualification.

The modern industrial age dictates improvement of new idea development and offers opportunities for transforming BSD teaching with the main aspects as follow: an exploration of business stability for business management optimization; analysis of the problems with identifying for knowledge creation that makes it possible to use data to effectively drive optimal decisions for modern strategic management (Mekvabidze et al., 2019).

The modern technology and the unified information space (UIS) that is rapidly occurring globally have a positive impact on engaging students and educators in critical thinking and problem-solving. Today, optimal decision making has to be included in the research studying process where the role of technology is a key to enrich business process optimization, which will be directed to gain the competitive 
skills and knowledge for business stability (Provost F.; Fawett T, 2013) that are tailored to customer requirements and decision-makers.

\section{Business Sustainability Development Perspectives for MBA\&M Level}

There are some of the different methodologies and technologies, in theory, to get the problem's solution, assess the results, and apply business process optimization at comparable prices of the Business Sustainability Development. In the study process of BS, the group of the subjects has to be considered as the important material for optimization model formulation and its solution (Florian N., Holger Schwartz, 2011). Still, generally, in the teaching process of BS, in practice, in the frame of modern education, the teaching considers knowledge and its management with the realization of the important components of today's environment through requirements and outcomes with a certain estimation of the optimal decision situation that leads to a known or expected outcomes. The process of computing the optimal decision consists of Constrained Optimization.

In the study process of BS as optimization model formulation and its solution, the main subjects are data science and analytics and operation research methods for optimization model formulation and its solution. In the practical sense, MBA\&M student is connected to the understanding how the student can foster optimal decision-making processes in practice for the need of BS development based on OR methods and business analytics or their combinations for instructing and implementing a model with its solution in the real situation (Niedermann F., Radeschutz S., Mitschang B. (2010): discussing conceptual aspects; discussing aspects of implementation; realization of a syllabus of the study module of BSD.

Business process optimization has arisen under the fast development of information technology and the trend towards globalization. Hence, business process performance under business process optimization is one of the sources of competitive advantage nowadays (Frank Medel-González, Lourdes García-Ávila, Adael Acosta-Beltrán and Cecilia Hernández 2013). It means that business research studying procedure has to be changed as research is a basis of business modeling, business management, and operation management. At the same time, decisionmaking knowledge covers many sciences and practical approaches, operation research methods, and it is a key subject for business and economics strategy management. To promote modernization of research Teaching for Practice, it is clear that we have to find the real answers to the two main questions Ruizan Mekvabidze (2018): what types of analysis can be conducted; what kinds of analysis can be used for improving the studying on the need level. It means improving business decisions by optimization methods, as follows: integrating data and analytics, formulating and solving complex optimization models, and incorporating risk management concerns. It is necessary to examine various 
approaches that promote students' knowledge improvement to respond to market requirements for the future as employers look for such specialists (Kaashiefa Mobarak, 2021).

\section{Active Education and Research for Promotion to the Sustainable Development Process}

Promotion to the sustainable development process under Active education and research have to be considered as follow: finding the characteristics in the learning environment that affect students interest, engagement for regulation studying process to competitive market requirements; to manage study environment and to stay and ensure Higher Education Institutions for creating new approaches T-L and manage to study environment; to consider the HE system as a bridge between T-LR-P and critical thinking and knowledge formation.

The effect of T-L-R-P objectives is developing and increasing students' potential to make responsible decisions think critically, and work within teams and groups efficiently. It means teacher as an organizer of knowledge; teacher and learners focus on asking questions and answering questions; teacher and learners focus on analyzing opinions to each other; teacher and learners focus on cooperation, responsibility, independence, communication skills problem solving, judgment, understanding; teacher and learners focus on logical thought; teacher and learners focus on research ideas; teacher and learners focus on the job market.

The main problem of the modern HEI is most closely connected with the globalization process and the 21st-century demands of competitive market requirements, which are in a relationship with the following components: the fast development of ICT; a process of globalization; transition to a market economy.

An outline seeks a comprehensive view of the higher education of integration of business process-oriented indicators for sustainable development: model building, optimal decision making, strategic management by proposing a model of decisionmaking as the main factor of the relationship between knowledge management and business performance. As a result, this relationship creates an operational and theoretical approach through a knowledge framework.

There is evident a relationship between business sustainability and business administration and management curriculum, and how the research components are bounded and included in curricula. Research with practice is one of the significant matters for sustainable business development. The research idea is focused on finding the direction of the real study program that would provide, on the one hand to sustainable business development and the other hand, learner's competitive job, and carrier. This motivation is analyzed and chosen the study module for the Master of Business Administration and Management (MBAM) program. We need to set common objectives and strategies by finding the essential key subjects for suggesting a new module for the MBAM program. 
The objectives of the research framework are to draw the student's objective for knowledge creation to business analytics, business model building with optimal decision making for the competitive job market; to bring the approaches of academics and teachers of the need to transform the program of training in business research, taking into account new technologies and the competitive job markets.

An essential way for business sustainability development is its integration with science. Barriers to cooperation are connected to the educational institutions, which are not always ready to transform business education curricula. Business representatives, in turn, do not always understand the competencies of the specialists they need. A crucial case is joint preparation of study programs of university integration with academic science and business. The critical issues that are important to education are student learning, politics, pre-service teaching programs, regulation of the scope of $\mathrm{T}-\mathrm{L}$, education landscape, changing world order/demand, and the other major challenges in higher education. The current thinking of the learning environment is based on the research element with its introduction in the teaching process with an active practice.

As an MBA\&M student's main skills develop under research and practice, HEI must promote research and research design with a conceptual understanding of innovation and transform it into knowledge management, and synthesize it with optimal decision-making strategies that are crucial factors for the formation of the needed study module of BS.

This approach develops a framework that helps graduates gain the skills they need for a competitive market. Such understanding leads to the teaching programs, which unite all tools under the sequential research process teaching with extracting results to the competitive market where graduates should be presented as the managers.

The vision of the changes of the study program is to address changes in subjects under the influence of the fast development of Information technology and business demand for stability: increasing research process studying for project-based research; introducing expansion modes of teaching and learning; developing business education for improving the students' critical skills for BS and BSD in the conditions of the globalization age; increasing approaches of universities to respond to student's demand.

What kind of changes do we have to consider from the side of graduates? As In the program of BSD for MBA\&M has to be considered to improve both theoretical and practical approaches, student needs: research methods teaching for projectbased research; improve an optimal decision making for practical usable on the project preparing level; a practice for preparation for analytical and critical thinking of sustainable development.

In a special module of BS where the main subjects for BS and BSD will be integrated, graduates will get the skills and practice of problem-solving needed for 
students' formation as modern critical thinking managers.

\section{Research Methodology and Research Results}

Because the main characteristics of business stability are as follows: a diverse set of resources, people and investments, insulation from shocks, the link between the organization and the external business and natural environment, assets and capabilities, important to shape a sustainable business model, cycles of growth and contraction, production, and consumer purchase patterns.

This research aims to draw the relationship of the academics, business actors, and MBA\&M students' consciences about studying BSD and BS, considering theoretical and practical approaches for revealing BS characteristics. Therefore, we have to consider a special teaching module with the needed subjects responsible for reaching $\mathrm{BSD} / \mathrm{BS}$. In the research, the frame was conducted the preparing questionnaires for academics, MAB\&M students, and business actors.

The variables were introduced accordingly for each questionnaire, with the specialization matching the variables assigned: Questionnaire 1: "Business Sustainability -1". Choosing the disciplines for BS one-year study from the disciplines. What disciplines do you prefer to study business sustainability development? The items/indicators of variable accordingly with the specialization that are matching the variables assigned it: Var 1. Knowledge management, Var 2. Business modeling, Var 3. Strategic management, Var 4. Business management, Var 5. Decision making, Var 6. Business research methods, Var 7. Operation research, Var 8. Quantitative research methods, Var 9. Mix - methods, Var 10. Game theory, Var 11. Risk analysis, Var 12. Program software for computing, Var 13. Strategic marketing, Var 14. Data science and analytics, Var 15. Human resources management, Var 16. System theory.

Questionnaire 2: "Business Sustainability-2". Choosing the disciplines for BSD one semester studying. Please, choose four or five disciplines by their content, consequently, that are acceptable for the study of business sustainability development. The variables are the same as for questionnaire 1.

Questionnaire 3 is: "Business Sustainability" - 3 according to the main characteristics of business stability. The items/indicators of variable accordingly with the specialization that are matching the variables assigned it: Var 1. The diverse set of resources, human resources and investments; Var 2. shocks and insulation from shocks; Var 3. The relationship between the organization and the external business and natural environment; Var 4. Assets and capabilities, important to shape a sustainable business model; Var 5. Cycles of growth and contraction, production, and consumer purchase patterns. Each group of questions includes a various number of items.

Data collections by the questionnaires were processed according to academics and business actors separately. For data processing, used program software STATA. 
Three criteria determined the appropriate sample size: the level of precision, the level of confidence, the degree of variability.

The developing questionnaires are used as a survey tool for this study. Participants were: academics, business actors, and MAB\&M students. The response options for research variables considered by the Likert Scale: Strongly agree (SA), Agree (A), Neutral (N), Disagree (DA), Strongly Disagree (SD).

The sample is formed for the three categories: academics, business actors, and MAB\&M students. The items as the data gathering tool (total 1500 copies) were sent by the internet but were collected 1320 copies giving a response $88 \%$, between of them $380-28.79 \%$ are from academics, $430-32.57 \%$ from Business actors, and $510-38.64 \%$ from the MAB\&M students. The demographic information is given in Table 1.

Table 1: Demographic information

\begin{tabular}{|c|c|c|c|}
\hline $\begin{array}{c}\text { Demographic } \\
\text { categories }\end{array}$ & Classification & Frequency & $\%$ \\
\hline \multirow{6}{*}{ Gender } & F (academics) & 135 & 35.52 \\
\hline & M (academics) & 245 & 64.47 \\
\hline & F (biasness actor) & 225 & 52.32 \\
\hline & M (biasness actor) & 205 & 47.67 \\
\hline & 2nd-year F (MAB\&M student) & 220 & 43.14 \\
\hline & 2nd-year M (MAB\&M student) & 290 & 56.86 \\
\hline \multirow{5}{*}{$\begin{array}{c}\text { Teaching } \\
\text { experience of } \\
\text { academics }\end{array}$} & Above 20 & 32 & 8.42 \\
\hline & Years: $15-20$ & 45 & 11.81 \\
\hline & Years: $11-15$ & 61 & 16.05 \\
\hline & Years: 5-10 & 114 & 30.00 \\
\hline & Under 5 years & 128 & 33.70 \\
\hline \multirow{5}{*}{$\begin{array}{c}\text { Teaching } \\
\text { experience of } \\
\text { business actors }\end{array}$} & Above 20 & 48 & 11.1 \\
\hline & Years: $15-20$ & 56 & 13.0 \\
\hline & Years: $11-15$ & 109 & 25.4 \\
\hline & Years: 5-10 & 104 & 24.2 \\
\hline & Under 5 years & 113 & 26.3 \\
\hline
\end{tabular}

The tests were carried out at the 0.05 level of significance. The reliability of items in the second section of the questionnaires was measured using Cronbach's alpha. The results of Cronbach's alpha are given in Table 2 below. 
Table 2: Reliability analysis of the indicators

\begin{tabular}{|c|c|c|c|}
\hline$\#$ & Variables & $\begin{array}{c}\text { Number of } \\
\text { Items }\end{array}$ & Cronbach's alpha \\
\hline 1 & Business Sustainability-1 & 16 & 0.77 \\
\hline 2 & Business Sustainability-2 & 16 & 0.69 \\
\hline 3 & $\begin{array}{c}\text { Business Sustainability with the main } \\
\text { characteristics }\end{array}$ & 5 & 0.74 \\
\hline
\end{tabular}

Analysis of the variables of BSD -1, BSD-2, and BSD-3 was used to explore the degree of consensus on the indicators of each variable. A review of the indicator statements related to the teaching of academics, business actors, and students shows that most academics, business actors, and students positively towards BSD. Respondents expressed a higher consensus of agreement on the statements (Table 3, 4, 5) below.

Table 3: Academics according to Business Sustainability Development-1 by the disciplines for one year studying

\begin{tabular}{|c|c|c|c|c|c|c|}
\hline \multirow{2}{*}{$\begin{array}{c}\text { Varia } \\
\text { ble }\end{array}$} & \multirow{2}{*}{ Items/indicators } & \multicolumn{5}{|c|}{ Frequency and \% } \\
\hline & & $\mathbf{S A}$ & A & $\mathbf{N}$ & DA & SD \\
\hline \multirow{25}{*}{ 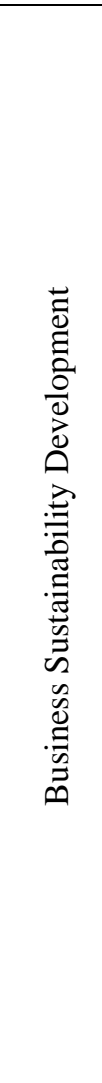 } & \multirow{2}{*}{ Knowledge management } & 13 & 10 & 4 & 0 & 0 \\
\hline & & $48.15 \%$ & $37.03 \%$ & $14.8 \%$ & & \\
\hline & \multirow{2}{*}{ Business modeling } & 10 & 9 & 5 & 0 & 0 \\
\hline & & $41.7 \%$ & $37.5 \%$ & $20.83 \%$ & & \\
\hline & \multirow{2}{*}{ Strategic management } & 11 & 11 & 2 & 0 & 0 \\
\hline & & $45.83 \%$ & $45.83 \%$ & $8.33 \%$ & & \\
\hline & \multirow{2}{*}{ Business management } & 10 & 8 & 3 & 0 & 0 \\
\hline & & $47.62 \%$ & $38.09 \%$ & $14.28 \%$ & & \\
\hline & \multirow{2}{*}{ Decision making } & 11 & 10 & 1 & 0 & 0 \\
\hline & & $52.38 \%$ & $47.62 \%$ & $4.8 \%$ & & \\
\hline & \multirow{2}{*}{ Business research methods } & 14 & 10 & 0 & 0 & 0 \\
\hline & & $58.33 \%$ & $41.66 \%$ & & & \\
\hline & \multirow{2}{*}{ Operation research } & 11 & 10 & 0 & 0 & 0 \\
\hline & & $52.38 \%$ & $47.62 \%$ & & & \\
\hline & \multirow{2}{*}{$\begin{array}{l}\text { Quantitative research } \\
\text { methods }\end{array}$} & 15 & 8 & 0 & 0 & 0 \\
\hline & & $65.22 \%$ & $34.78 \%$ & & & \\
\hline & \multirow[b]{2}{*}{ mix - methods } & 4 & 5 & 2 & 2 & 0 \\
\hline & & $35.36 \%$ & $45.45 \%$ & $18.18 \%$ & $\begin{array}{c}18.18 \\
\%\end{array}$ & \\
\hline & \multirow{2}{*}{ Game theory } & 12 & 6 & 3 & 0 & 0 \\
\hline & & $57.14 \%$ & $28.57 \%$ & $14.28 \%$ & & \\
\hline & \multirow{2}{*}{ Risk analysis } & 14 & 10 & 1 & 0 & 0 \\
\hline & & $56.00 \%$ & $40.00 \%$ & $4.00 \%$ & & \\
\hline & \multirow{2}{*}{$\begin{array}{l}\text { Program software for } \\
\text { computing }\end{array}$} & 11 & 8 & 6 & 0 & 0 \\
\hline & & $45.83 \%$ & $33.33 \%$ & $24.00 \%$ & & \\
\hline & Strategic marketing & 11 & 14 & 2 & 0 & 0 \\
\hline
\end{tabular}




\begin{tabular}{|c|c|c|c|c|c|c|}
\hline & & $40.74 \%$ & $51.85 \%$ & $7.40 \%$ & & \\
\hline & \multirow{2}{*}{ Data science and analytics } & 11 & 13 & 1 & 0 & 0 \\
\hline & & $44.00 \%$ & $52.00 \%$ & $4.00 \%$ & & \\
\hline & \multirow{2}{*}{ System theory } & 9 & 7 & 5 & 0 & 0 \\
\hline & & $42.85 \%$ & $33.33 \%$ & $23.81 \%$ & & \\
\hline & \multirow{2}{*}{ Human resources } & 12 & 11 & 3 & 0 & 0 \\
\hline & & $46.15 \%$ & 42.31 & $11.54 \%$ & & \\
\hline \multirow{10}{*}{ 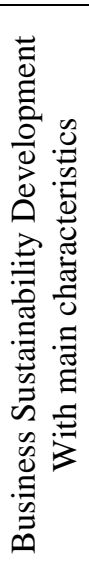 } & \multirow{2}{*}{$\begin{array}{l}\text { A diverse set of resources, } \\
\text { people, and investments }\end{array}$} & 21 & 32 & 9 & 0 & 0 \\
\hline & & $33.97 \%$ & $51.61 \%$ & $14.52 \%$ & & \\
\hline & \multirow{2}{*}{ Insulation from shocks } & 41 & 16 & 5 & 0 & 0 \\
\hline & & $66.12 \%$ & $25.80 \%$ & $8.06 \%$ & & \\
\hline & \multirow{2}{*}{$\begin{array}{l}\text { The link between the } \\
\text { organization and the } \\
\text { external business and } \\
\text { natural environment }\end{array}$} & 27 & 23 & 10 & 2 & 0 \\
\hline & & $43.54 \%$ & $37.09 \%$ & $16.13 \%$ & $3.22 \%$ & \\
\hline & \multirow{2}{*}{$\begin{array}{c}\text { Assets and capabilities, } \\
\text { important to shape a } \\
\text { sustainable business model }\end{array}$} & 28 & 28 & 6 & 0 & 0 \\
\hline & & $45.16 \%$ & $45.16 \%$ & $9.68 \%$ & & \\
\hline & \multirow{2}{*}{$\begin{array}{l}\text { Cycles of growth and } \\
\text { contraction, production, and } \\
\text { consumer purchase patterns }\end{array}$} & 28 & 32 & 2 & 0 & 0 \\
\hline & & $45.16 \%$ & $51.61 \%$ & $3.22 \%$ & & \\
\hline
\end{tabular}

Table 4: Business actors according to Business Sustainability Development -2 by the disciplines for one semester studying

\begin{tabular}{|c|c|c|c|c|c|c|}
\hline \multirow{2}{*}{ Variable } & \multirow{2}{*}{ Items/indicators } & \multicolumn{5}{|c|}{ Frequency and \% } \\
\hline & & SA & $\mathbf{A}$ & $\mathbf{N}$ & DA & SD \\
\hline \multirow{21}{*}{ 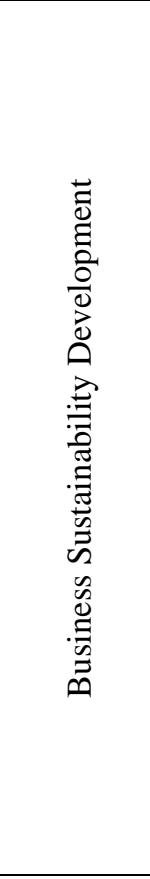 } & \multirow{2}{*}{ Knowledge management } & 11 & 17 & 0 & 0 & 0 \\
\hline & & $39.28 \%$ & $60.71 \%$ & & & \\
\hline & \multirow{2}{*}{ Business modeling } & 12 & 13 & 1 & 0 & 0 \\
\hline & & $46.15 \%$ & $50.00 \%$ & $3.84 \%$ & & \\
\hline & \multirow{2}{*}{ Strategic management } & 12 & 16 & 0 & 0 & 0 \\
\hline & & $48.00 \%$ & $53.57 \%$ & & & \\
\hline & \multirow{2}{*}{ Business management } & 13 & 15 & 0 & 0 & 0 \\
\hline & & $46.43 \%$ & $53.57 \%$ & & & \\
\hline & \multirow{2}{*}{ Decision making } & 7 & 19 & 0 & 0 & 0 \\
\hline & & $26.92 \%$ & $73.08 \%$ & & & \\
\hline & \multirow{2}{*}{ Business research methods } & 11 & 15 & 0 & 0 & 0 \\
\hline & & $42.30 \%$ & $57.69 \%$ & & & \\
\hline & \multirow{2}{*}{ Operation research } & 4 & 18 & 0 & 0 & 0 \\
\hline & & $18.18 \%$ & $81.81 \%$ & & & \\
\hline & \multirow{2}{*}{$\begin{array}{l}\text { Quantitative research } \\
\text { methods }\end{array}$} & 14 & 12 & 0 & 0 & 0 \\
\hline & & $53.38 \%$ & $46.15 \%$ & & & \\
\hline & \multirow{2}{*}{ Mix - methods } & 6 & 9 & 0 & 0 & 0 \\
\hline & & $40.00 \%$ & $60.00 \%$ & & & \\
\hline & \multirow{2}{*}{ Game theory } & 11 & 13 & 1 & 0 & 0 \\
\hline & & $45.83 \%$ & $54.17 \%$ & $0.16 \%$ & & \\
\hline & Risk analysis & 10 & 19 & 0 & 0 & 0 \\
\hline
\end{tabular}




\begin{tabular}{|c|c|c|c|c|c|c|}
\hline & & $34.48 \%$ & $65.51 \%$ & & & \\
\hline & \multirow{2}{*}{$\begin{array}{l}\text { Program software for } \\
\text { computing }\end{array}$} & 11 & 11 & 3 & 0 & 0 \\
\hline & & $44.00 \%$ & $44.00 \%$ & $12.00 \%$ & & \\
\hline & \multirow{2}{*}{ Strategic marketing } & 10 & 21 & 0 & 0 & 0 \\
\hline & & $32.25 \%$ & $67.74 \%$ & & & \\
\hline & \multirow{2}{*}{ Data science and analytics } & 9 & 18 & 0 & 0 & 0 \\
\hline & & $33.33 \%$ & $66.66 \%$ & & & \\
\hline & \multirow{2}{*}{ System theory } & 5 & 14 & 4 & 0 & 0 \\
\hline & & $21.74 \%$ & $69.86 \%$ & $17.39 \%$ & & \\
\hline & \multirow{2}{*}{$\begin{array}{l}\text { Human resources } \\
\text { management }\end{array}$} & 18 & 21 & 1 & 0 & 0 \\
\hline & & $45.00 \%$ & $52.50 \%$ & $2.50 \%$ & & \\
\hline \multirow{7}{*}{ 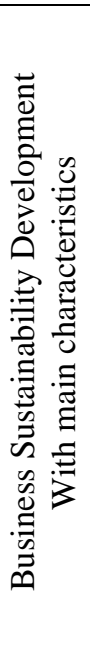 } & \multirow{2}{*}{$\begin{array}{l}\text { A diverse set of resources, } \\
\text { people and investments }\end{array}$} & 30 & 50 & 6 & 0 & 0 \\
\hline & & $34.88 \%$ & $58.14 \%$ & $6.98 \%$ & & \\
\hline & \multirow{2}{*}{ Insulation from shocks } & 16 & 70 & 0 & 0 & 0 \\
\hline & & $18.60 \%$ & $81.39 \%$ & & 0 & 0 \\
\hline & $\begin{array}{l}\text { The link between the } \\
\text { organization and the } \\
\text { external business and } \\
\text { natural environment }\end{array}$ & $\begin{array}{c}32 \\
37.20 \%\end{array}$ & $\begin{array}{c}40 \\
46.51 \%\end{array}$ & $\begin{array}{c}14 \\
16.27 \%\end{array}$ & 0 & 0 \\
\hline & $\begin{array}{c}\text { Assets and capabilities, } \\
\text { important to shape a } \\
\text { sustainable business } \\
\text { model }\end{array}$ & $\begin{array}{c}33 \\
38.37 \%\end{array}$ & $\begin{array}{c}52 \\
60.46 \%\end{array}$ & $\begin{array}{c}11 \\
12.79 \%\end{array}$ & 0 & 0 \\
\hline & $\begin{array}{l}\text { Cycles of growth and } \\
\text { contraction, production, } \\
\text { and consumer purchase } \\
\text { patterns }\end{array}$ & $\begin{array}{c}24 \\
27.90 \%\end{array}$ & $\begin{array}{c}45 \\
52.32 \%\end{array}$ & $\begin{array}{c}17 \\
19.76 \%\end{array}$ & & \\
\hline
\end{tabular}

Table 5: MAB\&M students according to Business Sustainability Development -2 by the disciplines for one semester studying

\begin{tabular}{|c|c|c|c|c|c|c|}
\hline \multirow[t]{2}{*}{ Variable } & \multirow[t]{2}{*}{ Items/indicators } & \multicolumn{5}{|c|}{ Frequency and \% } \\
\hline & & SA & $\mathbf{A}$ & $\mathbf{N}$ & DA & SD \\
\hline \multirow{15}{*}{ 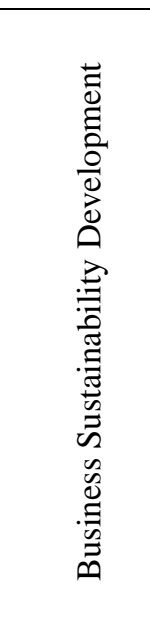 } & \multirow{2}{*}{ Knowledge management } & 15 & 25 & 7 & & \\
\hline & & & & & 0 & 0 \\
\hline & \multirow{2}{*}{ Business modeling } & 7 & 12 & 13 & & \\
\hline & & & & & 0 & 0 \\
\hline & \multirow{2}{*}{ Strategic management } & 6 & 17 & 7 & & \\
\hline & & & & & 0 & 0 \\
\hline & \multirow{2}{*}{ Business management } & 3 & 21 & 6 & & \\
\hline & & & & & 0 & 0 \\
\hline & \multirow{2}{*}{ Decision making } & 5 & 20 & 5 & & \\
\hline & & & & & 0 & 0 \\
\hline & \multirow{2}{*}{ Business research methods } & 30 & & & & \\
\hline & & & & & 0 & 0 \\
\hline & \multirow{2}{*}{ Operation research (23) } & - & - & - & & \\
\hline & & & & & 0 & 0 \\
\hline & Quantitative research & 4 & 18 & 4 & & \\
\hline
\end{tabular}




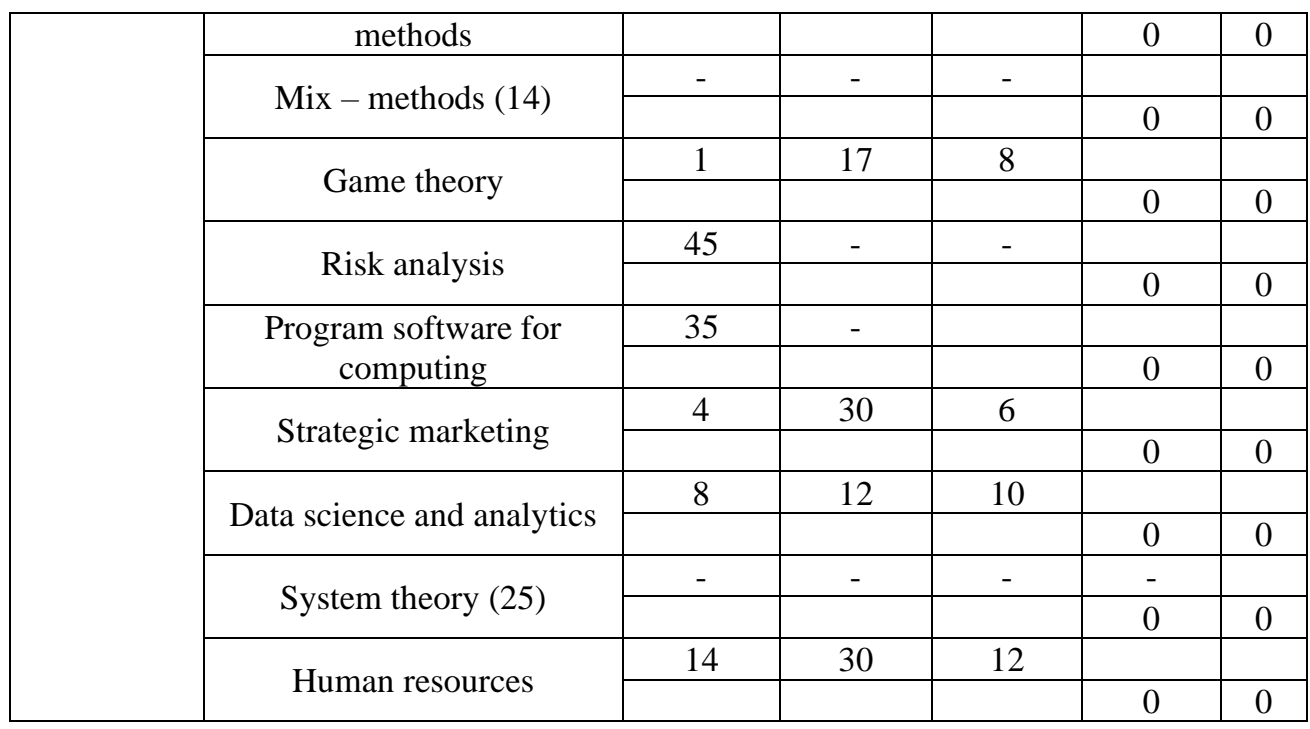

Table 6: Summary results with the positive answers by the variables

\begin{tabular}{|c|c|c|c|c|}
\hline Items/Indicators & BS-1 & BS-2 & BS-3 & Priorities \\
\hline Knowledge management & + & + & & + \\
\hline Business modeling & & + & & \\
\hline Strategic management & + & + & & \\
\hline Business management & & + & & \\
\hline Decision making & + & + & & + \\
\hline \multicolumn{5}{|l|}{ Business research methods } \\
\hline \multicolumn{5}{|l|}{ Operation research } \\
\hline Quantitative research methods & + & + & & + \\
\hline \multicolumn{5}{|l|}{ Mix - methods } \\
\hline \multicolumn{5}{|l|}{ Game theory } \\
\hline Risk analysis & + & + & & + \\
\hline Program software for computing & + & + & & \\
\hline Strategic marketing & + & + & & + \\
\hline Data science and analytics & + & + & & + \\
\hline \multicolumn{5}{|l|}{ System theory } \\
\hline Human resources & + & + & & \\
\hline $\begin{array}{c}\text { A diverse set of resources, people, and } \\
\text { investments }\end{array}$ & & & + & \\
\hline Insulation from shocks & & & + & + \\
\hline $\begin{array}{l}\text { The link between the organization and the } \\
\text { external business and natural environment }\end{array}$ & & & + & + \\
\hline $\begin{array}{c}\text { Assets and capabilities, important to shape a } \\
\text { sustainable business model }\end{array}$ & & & + & + \\
\hline $\begin{array}{l}\text { Cycles of growth and contraction, production, } \\
\text { and consumer purchase patterns }\end{array}$ & & & + & + \\
\hline
\end{tabular}




\section{Conclusion}

This study focuses on the functional relationship of business sustainable development and the influence of the educational indicators of model building, decision making, and knowledge management for the developing study module for Master of Business Administration \&Management (MAB\&M). The work presented the considering and comparing the teaching and learning of MBA\&M students by the vision of academics, business actors, and MBA\&M students according to the studying of the major subjects by the syllabuses. The knowledge of subjects' is responsible for business stability, and how the student is ready to gain the knowledge on business management and its stability as business education performance is a way to the sustainability business process. There are considered three versions of business stability (BS) by the major subjects as are:

BS-1 by the vision of academics which are recommended for teaching-learning set of items for one year studying: Knowledge management - 89\%, Quantitative business research methods - 99\%, Risk analysis - 90\%, Data science and analytics - 98\%, Strategic Marketing - 88\%, decision making - 99\%, Human Recourses $92 \%$.

BS-2 by the vision of business actors which are recommended for teachinglearning set of items for one year studying: Knowledge management, Quantitative business research methods, Risk analysis, Data science and analytics, Strategic Marketing, Decision making, Human Recourses recommended on the maximum level $99 \%-100 \%$.

BS-2, according to the vision of MBA \& M students, is reasonable, which are recommended for teaching-learning a set of assignments for one year of study and students have little understanding of all subjects. Still, they give preference to subjects Knowledge management, business research methods, IT platform, Strategic Marketing, Decision making, Human Recourses.

According to the BS-3, we may talk that it is a perfect version as it includes all the needed components for business stability and its development in the future. The students do not understand this version as its essence is dependent on practice.

\section{References}

Bakradze L. (2013). Strategic Development of Higher Education and a Science Integration of Teaching and Research. Tbilisi: The International Institute of Education Policy, Planning and Management (EPPM). <https://eppm.org.ge/en/>.

Florian N., \& Holger, S. (2011). Deep business optimization: making Business process optimization. Theory Work in Practice. https://doi.org/10.1007/978-3-64221759-3_7. 
Frank, M., Lourdes G., Adael A. B., \& Cecilia, H. (2013). Measuring and Evaluating Business Sustainability: Development and Application of Corporate Index of Sustainability Performance. Book: Sustainability Appraisal: Quantitative Methods and Mathematical Techniques for Environmental Performance Evaluation. Publisher: Springer Berlin Heidelberg, https://doi.org/10.1007/978-3-642-32081-1-3, 11/11/2021.33-61.

Fred R. D. (2016). Strategic Management: A competitive Advantage, Approaches, Concepts and cases. 16th edition, Pearson. 284-289.

Kaashiefa, M. (2021). Exploring the contribution of universities to labour market requirements in South Africa: An employer's perspective. Journal Industry and Higher education: 35(2), 114-124.

Kerlinger, A research design. (1986). 279 p., <https://www.coursehero.com

Klaus Schwab. (2020). Head of the World Economic Forum 2019, <https://www.weforum.org/reports/annual-report-2019-2020>.

Mekvabidze Ruizan (2015). Approaches to the Modern University: Student Engagement in Learning Outcome for Knowledge Creation According to the Competitive Market Requirements. Journal of System and Management Sciences, 5 (4), 1-30.

Niedermann F., Radeschutz S., \& Mitschang B. (2010). Deep business optimization: A platform for automated process optimization. Proceedings of the 3rd International Conference on business process and services computing. $<$ https://citeseerx.ist.psu.edu/viewdoc/download?doi=10.1.1.407.7319\&rep=rep1\&t ype=pdf 28.11.2021>

Provost, F., \& Fawett T. (2013). Data science and its relationship to Big Data and Data-Driven making.

Ruizan, M. (2015). Life in transition: Problems and solutions of internationalization of Higher education and Its Promotion. European Journal of Transformation Studies, <http://europeourhouse.weebly.com/ejts.html>.

Ruizan, M. (2016). Decision Making Technology in Practice Quantitative Methods and Models. Text book for MA Students of "Business Organization and Management". Publishing House: UNIVERSAL. ISBN:978-941-22- 860-5 p.: 329 (In Georgian). 
Ruizan, M. (2018). Teaching Tomorrow-Today: Study Module of Business Management. 7th International Scientific conference "Cultural, Social and ethical determinants of business, economy, management and national security". Opole Technological University, Poland. ISSN 1429-6063, ISBN: 978-83-66033-20-8, Studia i Monografie z.490, 191-2011.

Ruizan, M. (2019). Teaching Research Business Methods. International Scientific Conference, Opole University of Technology, October 29, 2019. Studia i Monografie, ISBN 978-83-66033-55-9, Opole, 271-275.

Ruizan, M.. (2021). Fostering decision-making in practice in the teaching process (Study Module: Decision-making in practice for knowledge management). The 22nd Conference of the International Federation of Operational Research Societies, 23-27 August 2021, Seoul.

Sherry, S., \& Baruch, Y. (2009). Advances in Career Theory and Research: A Critical Review and Agenda for Future Exploration. Journal of management: 35(6), 1542-1571. https://doi.org/10.1177/014920630935008.

Sherry E. S., \& Baruch, Y. (2009). Advances in Carrier Theory and Research: A Critical Review and Agenda for Future Exploration. 